\title{
Maroon Societies: A Political Perspective Chantal McFarlane
}

Chantal Noelene McFarlane is a third year student at the University of Toronto. She is presently pursuing her undergraduate degree in Caribbean Studies and English. As a proud descendant of the Accompong Town Maroons in Jamaica, she is a staunch believer in the concept of "Kindah", One Family - she believes that this can manifest in the Caribbean in the form of regional integration. Chantal is particularly interested in the cultural, social and historical aspects of Jamaica.

The act of grand marronage had a far reaching impact on slave societies. Marronage in its most simplistic sense may be described as the running away from slavery by the enslaved. In Jamaica ${ }^{1}$ slaves who absconded for great periods tended to live by themselves or join a Maroon settlement. This essay will argue that Maroon societies acted as an entity of defiance against slave communities, even though intricate organizational structures had an atypical symbiotic relationship with them. It will show that the political aspect of Maroon societies acted as a dominant factor in solidifying their relationship with slave communities. This paper will first establish that Maroons in Jamaica were more autonomous prior to 1739 and that the difference in political structures from that of the plantation was pivotal in shaping the relationship between the two societies. It will then argue that the political scope of Maroon societies impacted the culture and socio-economic organization of the Maroons. Finally it will posit the idea that a significant change in the relationship between Maroons and the plantation in Jamaica acted as an impetus which changed the political configuration of Maroon communities.

Alvin Thompson defines marronage as absconding from "the system of oppression" (slavery), ${ }^{2}$ hence it can be viewed as a definite form of resistance to slave-holding societies. The plantation was severely affected by marronage in that it lost valuable labour which in turn cut into profit. Slaves that committed marronage on a

1 This paper will look specifically at the political aspect of Maroon societies in Jamaica. It will briefly look at the formation of Maroon societies from 1655; however it will concentrate mostly on fully developed societies from late 1600 s to mid-1700s.

2 Alvin Thompson, Flight to Freedom: African Runaways and Maroons in the Americas (Kingston: University of the West Indies Press, 2006), 9. 
grand scale usually joined with other slaves who had run away, they would then "create independent communities of their own, " known as Maroon societies; these societies were ones "that struck directly at the foundations of the plantation system."3 Such "ex-slaves' congregated and interacted extensively with the slaves still on the plantations. According to Mavis Campbell, Maroon societies are communities that are self-governed and "outside the purlieus of the slave plantations." 4 Even though Maroon societies are described as being outside the governance of the plantocracy they still shared an unusual mutually beneficial relationship with them. The political, economic, cultural and social organization of Maroon communities was very much intertwined with the structural organization of the plantation. The political aspect however acted as the cementing factor in binding Maroon societies and plantations together. The political variance in Jamaican Maroon communities provides a comparative example under which this can be analyzed; changes in the political setting over time significantly altered the organization of Maroon societies.

The first identified Maroon settlements were established in Jamaica by Spanish slaves who fled into the mountainous regions when the English took over the island in $1655 . .^{5}$ This was the beginning of a new threat to slavery as an institution. Maroon towns were created based on "strict security consideration." 6 Towns were formed in the mountainous interiors of Jamaica so as to make it inaccessible for white planters who would raid the areas and reenslave Maroons. The political structure of Jamaican Maroons during the initial years of their formation was one that is sometimes described as a form of despotism, one autonomous from the plantation. ${ }^{7}$ Alvin Thompson asserts however that a major difference between slave societies and Maroon societies fuelled the need for such political distinctiveness. Specifically, he states that Maroon societies were "born out of the quest for freedom" and the plantation was constructed out of "the quest for material gain." This variance in the political organization of each society reflects a deeper

\footnotetext{
3 Richard Price, Maroon Societies: Rebel Slave Communities in the Americas. (New York: Anchor Books, 1973), 3.

4 Mavis Campbell, The Maroons of Jamaica 1655-1796, (Trenton: African World Press, 1990),

5 Ibid 14

6 Ibid, 47.

${ }^{7}$ Alvin Thompson, Flight to Freedom, 211
} 
significance, which is that the very formation and survival of emerging Maroon societies was contingent on a particular political organization that embraced collective solidarity and defence. ${ }^{8}$ Barbara Kopytoff argues that the period of political formation before the first treaty between the Maroons and the Jamaican government may be viewed as the only point when the political institutions of Maroon societies were outside the influence of colonial rule. 9 This period had the chiefs much more involved in maintaining order within the community.

The selection of a leader was crucial to signing treaties between the Maroons and the Jamaican government. Politically, having a Creole leader was advantageous to Maroon societies as this person would be able to understand both whites and their fellow Maroons. ${ }^{10}$ "Creole" in this context refers to slaves that were born in the 'New World' and not in Africa. The creole preference in leadership kept Maroon communities together so as to lessen preferential treatment for persons who came from particular tribes. The notion of tribalism being less charged, runaway slaves who then wanted to join did not have to fret about being refused entry into these groups because of their status as a creole, or a slave directly from Africa. Initial Maroon groups were usually led by African-born slaves who defected from the plantation. This however would result in internal strife within or between varying groups of Maroons. ${ }^{11}$ The political choice of creole slaves as leaders was one that changed the relationship between the plantation and these communities.

Jamaica was initially divided into two specific groups of Maroons, the Windward and the Leeward. Leeward Maroons inhabited the west under the leadership of Cudjoe while the Windward Maroons branched out under various leaders, the most notable being Nanny. ${ }^{12}$ Karla Gottlieb notes that a major distinguishing factor between the two was that Leeward Maroons had in general recently escaped from their plantations and did not want to engage with the British whereas the Windward Maroons were descendants of the original Spanish Maroons, hence "their

\footnotetext{
8 Richard Price, Maroon Societies ,19-20

9 Kopytoff, 306.

10 Price, 20.

11 Kopytoff, 295.

12 Price, 49.
} 
determination to hold on to their lands." ${ }^{13}$ The Leeward Maroons of Jamaica were governed sternly by Cudjoe; he had inherited his position from his father who had led rebellions in the late 160os. ${ }^{14}$ Bryan Edwards in his account of the Maroons in Jamaica speaks of Cudjoe as "a very able general." 15 Cudjoe's political clout in his Maroon band was significant, especially when it raided plantations for food. Barbara Kopytoff in her article "The Early Political Development of Jamaican Maroon Societies" argues that even though Cudjoe was perceived as an authoritarian figure, when his gang raided plantations they were strictly forbidden from harming whites unless provoked. ${ }^{16}$ Maroons were usually divided into groups along military lines; the society then was a hierarchical one that reflected ability and military capabilities. Cudjoe divided his Leeward maroons into 'politico-military' companies ${ }^{17}$ and by doing this, he was better able to manage the Maroons and keep the settlements together.

Nanny was seen as the main leader of the Windward Maroons in the early 1700 , even though their group was highly fragmented. Historical accounts of Nanny's reign are generally oral and thus historians are highly ambivalent about certain aspects of her representation. The high position held by Nanny refutes observations of Bryan Edwards which posited lower social roles for female Maroons in that society. Edwards notes that women held lowly statuses in society and that they were viewed as a "beast of burden." 18 Nevertheless, women were pivotal in the clearing of land and performing agricultural tasks. Also, the fact that Nanny emerged as a fully recognized and respected leader by both her Maroon followers and the plantocracy is proof of a greater status given to the female subject. Karla Gottlieb argues this extensively in stating through Kenneth Bilby and Filomina Steady that Maroon societies

\footnotetext{
13 Karla Gottlieb, The Mother of Us All (New Jersey: Africa World Press, 2000), 6.

14 Barbara Klamon Kopytoff, "The Early Political Development of Jamaican Maroon Societies" in The William and Mary Quarterly,(1978), 295.

15 Brian Edwards, "Observations on the Disposition, Character, Manners and Habits of Life of the Maroon Negroes of the Island of Jamaica." Richard Price ed. Maroon Societies: Rebel Slave Communities in the Americas. (Baltimore: John Hopkins University Press. 1996) , 233.

16 lbid, 297.

17 Campbell, 46

18 Edwards, 241
} 
were highly matrifocal and women could be viewed as the "main source of stability and continuity within the group." 19

The prominence of Maroon societies throughout Jamaica in the late seventeenth and early eighteenth centuries became a major cause of concern for the government of that time. The very fact of an autonomous ex-slave community within the confines of slave society was a great treachery to those who owned the enslaved. The adaptability of the political structure to the development of new institutions was needed because if aspects of the early social and political organization were not altered then the possibility of the Maroon society surviving was slim..$^{20}$ The change that occurred after the signing of the treaty reduced the threat of grand marronage.

The political structure of Maroon society was heavily connected to the religious belief in Obeah. Obeah in part is a belief in supernatural powers usually intended to summon spiritual ancestral ties. The use of Obeah was pivotal to governing Maroon societies by the chiefs. Bryan Edwards argues that the power which Obeah men held over Maroon communities "was sometimes very successfully employed" in keeping the Maroon population subordinate to the chiefs. ${ }^{21}$ In Jamaica, Nanny was purportedly able to catch bullets in her buttocks.22 This kind of super human quality added to the aura of chiefs as perceived by the government of the country. Hence, the fact that Nanny had swelled ranks was due to the fact that she possessed these "uncanny spiritual powers as her martial capabilities." 23 These kinds of abilities were not only impressive to the Maroons but also to those in slave societies. The political implications of this within the militarized setting of a Maroon society would mean that the spiritual person would be placed in a high position of council. Those who occupied such positions were instrumental in fighting the wars that raged between Maroon communities and the Jamaican government.

The fact that the early Maroon societies had to depend on the plantation for food meant that the Maroons had to disrupt plantation life. These disruptions, as well as the fact that slaves were running away to join the ranks of the Maroons, were not taken

\footnotetext{
19 Gottlieb, 12-13.

20 Price, 21.

21 Edwards, 240.

22 Thompson, 232.

23 Ibid, 232.
} 
lightly by the planters. This resulted in wars between the Jamaican government and the Maroons - the "First Maroon War" lasted from the mid-1720s until $1740 .{ }^{24}$ In this war the Maroons outwitted the planters and incited the absconding of other slaves. The treaty signed by the Leeward Maroons with Colonel Guthrie on March $1^{\text {st }}, 1739$ gave full recognition to the Maroon communities as autonomous areas; Maroons were granted land ownership rights, and the ability to sell their produce in markets openly. ${ }^{25}$ The most important clause in this treaty according to Orlando Patterson stated that all future runaway slaves to Maroon groups were to be returned to their masters. The Maroons would then be paid for this service, causing a political rift within the Leeward Maroon settlements and within the plantations. The very act of agreeing to the treaty meant that Cudjoe essentially took away the possibility for the enslaved to resist slavery, thereby bounding them to the plantation. The salient fact that needs to be stressed is that the political organization of Maroon societies interacted with the social, economic, and the cultural aspects of the society, in the process, changing the relationship between Maroon settlements and the plantation.

The treaties that were agreed upon between the Jamaican government and the Maroon communities severely lessened the authority of the Maroon chief. Richard Price argues that they had a debilitating effect on the Maroon society because the major "cornerstone" of the political regime was removed. Barbara Kopytoff notes that the signing of the treaty significantly debilitated the autonomous power Maroons once had and affected forms of political cohesion that could have limited internal strife. Laws that governed these communities were also revoked and penalties for breaking a law under the treaty became punishable by the Jamaican government. This change had a significant impact on the Maroon community as certain internal mechanisms enabled chiefs to retain their authority. The imposition of the death penalty for example gave political credence to the chief in a Maroon society. ${ }^{26}$

The treaty that was signed in 1739 between the Maroons and the Jamaican government changed the political organization of Maroon societies, thus it significantly altered their relationship to

\footnotetext{
24 Orlando Patterson. "Slavery and Slave Revolts: A Socio-historical Analysis of the First Maroon War. 1665-1740.” Ed. Michael Price. Maroon Societies. 246

$25 \mathrm{lbid}$

26 Ibid, 228.
} 
the colonial order. Barbara Kopytoff asserts that Maroon communities declined significantly as a result of this treaty. She states further on that the treaties gave Maroons an ambiguous position in the country as they no longer occupied an autonomous realm nor did they fall into "the traditional pyramid used to depict the social organization of Caribbean plantation slave societies." 27 This precarious positioning of Maroons affected the slaves directly as runaways under the treaty had to be returned; this highlights the fact that the situation for the Maroons did not necessarily have a positive outcome for the enslaved. Alvin Thompson provides a counter argument however when he notes that even before the treaty, Maroons would return runaway slaves for "material gains." 28 This of course counters the belief of Maroon societies as being exclusively accepting of runaways. The historic importance of the negotiations between Maroons and the Jamaican government is one that is based heavily on the political structure of Maroons before 1739. The changing political organization of Maroon societies reshaped the relationship between Maroons and the plantation system. Maroon societies went from being fully autonomous to being areas that were co-governed by Maroon chiefs as well as the governor of colonial Jamaica.

27 Barbara Kopytoff. "Colonial Treaty as Sacred Charter of the Jamaican Maroons.” Ethnohistory, Vol. 26, No.1. 1979: 50.

28 Thompson, 308. 


\section{Works Cited}

Campbell, Mavis, The Maroons of Jamaica, 1655-1796: A History of Resistance, Collaboration and Betrayal Granby, Mass.: Bergin \& Garvey, 1988.

Dubios, Laurent. "Essay Review I: On the History of The Jamaican Maroons" in The Journal of African American History Vol. 93, No.1. 2008, 64-69.

Edwads, Bryan. "Observations on the Disposition, Character, Manners and Habits of Life of the Maroon Negroes of the Island of Jamaica." Richard Price ed. Maroon Societies: Rebel Slave Communities in the Americas. Baltimore: John Hopkins University Press. 1996: 230-245.

Gottlieb, Karla. "The Mother of Us All”: A History of Queen Nanny Leader of the Windward Jamaican Maroons. Trenton: Africa World Press. 2000.

Kopytoff, Barbara Klamon."The Early Political Development of Jamaican Maroon Societies" in The William and Mary Quarterly, Third Series, Vol. 35, No. 2 (Apr., 1978), pp. 287-307.

Kopytoff, Barbara Klamon. "Colonial Treaty as Sacred Charter of the Jamaican Maroons" Ethnohistory, Vol.26 No.1 1979:45-64.

Patterson, Orlando. "Slavery and Slave Revolts: A Socio-historical Analysis of the First Maroon War. 1665-1740." Richard Price ed. Maroon Societies: Rebel Slave Communities in Americas. Baltimore: John Hopkins University Press. 1996: 246-292

Price, Richard ed. "Introduction." Maroon Societies: Rebel Slave Communities in the Americas. New York Anchor Books, 1973.

Thompson, Alvin. Flight to Freedom: African Runaways and Maroons in the Americas Kingston: University of the West Indies Press, 2006. 